\title{
Polymorphism of 5'UTR myostatin gene indel (g.1256/TTTTA) and its association with body weight in Boerka crossbred goat
}

\author{
R. Ismail ${ }^{1,3}$, E. Handiwirawan ${ }^{2}$, S. Elieser ${ }^{3}$ and J. Jakaria ${ }^{4}$,* \\ ${ }^{1}$ Graduate Program in Animal Production and Technology, Faculty of Animal Science, \\ IPB-University, Jl. Agatis, Dramaga Campus, Bogor 16680 - Indonesia \\ ${ }^{2}$ Indonesian Center for Animal Research and Development, Jl. Raya Pajajaran Kav.E-59, \\ Bogor 16151, West Java - Indonesia \\ ${ }^{3}$ Permanent Address: Indonesian Goat Research Center, Sungei Putih PO Box.1, \\ Galang, Deli Serdang, North Sumatera - Indonesia \\ ${ }^{4}$ Department of Animal Production and Technology, Faculty of Animal Science, \\ IPB University, Jl Agatis, Dramaga Campus, Bogor 16680 - Indonesia \\ *Corresponding E-mail : jakaria@apps.ibp.ac.id
}

Received April 09, 2020; Accepted June 26, 2020

\begin{abstract}
ABSTRAK
Penelitian ini bertujuan mengidentifikasi keragaman fragmen 5'UTR gen Myostatin (MSTN) dan asosiasinya terhadap bobot badan kambing Boer, Kacang, dan Boerka. Sampel DNA diambil sebanyak 149 buah dari Loka Penelitian Kambing Potong Sungei Putih, Sumatera Utara. Identifikasi polimorfisme menggunakan metode direct sequencing dan Polymerase Chain Reaction - Restriction Fragment Length Polymorphism (PCR-RFLP). PCR-RFLP menggunakan enzim restriksi DraI terhadap indel g.1256/TTTTA. Analisis ragam bobot badan dilakukan dengan General Linear Model (GLM). Hasil penelitian menunjukkan bahwa fragmen 5'UTR gen MSTN monomorfik pada kambing Kacang namun polimorfik pada kambing Boer dan Boerka. Frekuensi genotipe kambing Boer 0,40(AA), 0.43(AB), 0.17(BB); Kacang 1.00(AA); Boerka 0.53(AA), 0.37(AB), 0.10(BB). Frekuensi alel kambing Boer 0.62(A), 0.38(B); Kacang 1.00(A); Boerka 0.72(A), 0.28(B). Frekuensi genotipe AB paling tinggi pada Boer, namun frekuensi genotipe AA paling tinggi pada Kacang dan Boerka. Indel g.1256/TTTTA berpengaruh signifikan $(\mathrm{P}<0,05)$ hanya pada bobot lahir $(\mathrm{BW})$ kambing Boer, namun tidak signifikan terhadap parameter bobot badan lainnya baik pada kambing Boer maupun Boerka. Genotipe AA memiliki bobot lahir paling tinggi $(\mathrm{P}<0,05)$ dari $\mathrm{AB}$, namun tidak berbeda nyata dengan genotipe $\mathrm{BB}$. Indel g.1256/TTTTA dapat dijadikan sebagai penciri genetik untuk sifat pertumbuhan (bobot lahir) kambing Boer namun tidak pada Boerka.
\end{abstract}

Kata kunci : 5 'UTR, Indel TTTTA, gen MSTN, RFLP, sekuensing

\section{ABSTRACT}

This study aimed to identify the variation of 5'UTR Myostatin (MSTN) gene and its association to body weight in Boer, Kacang, and Boerka goats. DNA samples were obtained from 149 heads of the goats from the Indonesian Goat Research Center, Sungei Putih, North Sumatera. Polymorphism identification was conducted by direct sequencing and PCR-RFLP with DraI as the restriction enzyme for indel g.1256/TTTTA. Analysis of variance for body weight was carried out using the General Linear Model (GLM). The 5'UTR MSTN gene|DraI was monomorphic in Kacang but polymorphic in Boer and Boerka. Genotype frequencies for Boer 0.40(AA), 0.43(AB), 0.17(BB); Kacang 1.00(AA); Boerka 
0.53(AA), 0.37(AB), 0.10(BB). The allele frequencies for Boer 0.62(A), 0.38(B); Kacang 1.00(A); Boerka 0.72(A), 0.28(B), respectively. $\mathrm{AB}$ was the most frequent genotype among Boer, but $\mathrm{AA}$ was the most frequent in Kacang and Boerka. Indel g.1256/TTTTA has a significant effect $(\mathrm{P}<0.05)$ only on birth weight (BW) of Boer, but no significant effect on other bodyweight parameters both in Boer and Boerka. AA genotype has the highest $\mathrm{BW}(\mathrm{P}<0.05)$ than $\mathrm{AB}$, but it's not significantly different from $\mathrm{BB}$. Indel g.1256/TTTTA could be used as a genetic marker for the birth weight of Boer but not in Boerka goats.

Keywords: 5'UTR, indel TTTTA, MSTN gene, RFLP, sequencing

\section{INTRODUCTION}

Kacang goat is one of Indonesia's local livestock. These goats were set as Indonesian domestic goat breed based on a decision of the Indonesian Minister of Agriculture No: $2840 / \mathrm{Kpts} / \mathrm{LB} .430 / 8 / 2012$. The superiorities of Kacang goats are known; have a good environment adaptive ability (Santoso et al., 2016; Septian et al., 2015), quickly produce offspring (Wahyuni et al., 2016), and more resistant to parasitic gastrointestinal infections (Batubara, 2006). As a tropical breed, Kacang goat was prolific (Panjono et al., 2012), smaller body size but had many offspring (Mulyono et al., 2018). Low body weight with an adult male weight of $24.05 \pm 3.95 \mathrm{~kg}$ makes Kacang goat not as ideal as meat-producing livestock (Batubara $e t$ al., 2012; Wahyuni et al., 2016).

One effort to improve the genetic quality of Kacang goats was through crossing with Boer buck goat. Boer goat was a beef type with fast body growth, good meat quality, and parasitic tolerance (Chong et al., 2019; Elieser et al., 2012; García-Muñiz et al., 2019). Boer has weaning weights $23.4 \pm 9.7 \mathrm{~kg}$ at the age of 112 days (Menezes et al., 2016) and adult male 120-150 kg at the age of 2-3 years (Nurgiartiningsih et al., 2006). Boer and Kacang goat crosses were called Boerka goat that a new superior goat (Ginting and Mahmilia, 2008). The Boerka goat was reported to have a birth weight, weaning weights, one-year weight, body weight gain, and carcass percentage higher than the Kacang goat (Doloksaribu et al., 2005; Priyanto et al., 2002; Setiadi et al., 2001; Triyantini et al., 2002). The genetic quality of Kacang goats can be improved through molecular-based growth selection. One gene that can be used was the MSTN gene because that affects the growth of muscle mass (Batubara, 2017; El Shafey et al., 2016).

MSTN was a member of the transforming growth factor-beta superfamily, which is also known as the growth differentiation factor (GDF)
8 (Hayashi et al., 2018). MSTN acts negatively towards the regulation of skeletal muscle mass development (Sun et al., 2020; Yue et al., 2020). The MSTN gene inhibits the work of the Myf5 and MyoD gene factors, which are related to the mechanism of differentiation of precursor cells into myoblasts (McPherron and Lee, 1997). The deactivation of the MSTN gene influences adipose tissue mass in addition to bone muscle mass (Dominique and Gérard, 2006) and associated with muscle hypertrophy (Kvedaras et al., 2019). This gene was specifically expressed during the development of the embryonic phase and adult skeletal muscle. MSTN gene polymorphisms cause growth acceleration and muscle mass of yellow catfish (Zhang et al., 2020), double muscular in cattle and goat (Grisolia et al., 2009; He et al., 2018), affect the carcass quality and lamb meat quality (Grochowska et al., 2019). MSTN gene polymorphisms were exciting things that could be used to increase livestock meat production (Aiello et al., 2018).

Some goats breed shown polymorphisms in the MSTN gene. Several studies reported the existence of 5'UTR polymorphisms in local goats in Iran (Abdolmohammadi et al., 2016), China (Li et al., 2008; Zhang et al., 2012), and India (Singh et al., 2014). 5'UTR was the region of the mRNA upstream from the protein-coding region (Manzella et al., 2020). 5'UTR has an important role such as; affect the level of mRNA transcription, mRNA decay, translation rates (Feng et al., 2019), control the process of translational initiation (Arend et al., 2018), translational repression mediator (Theil et al., 2018), and regulation of gene expression (Araujo et al., 2012; Liao et al., 2013; Zhang et al., 2018). The indel of TTTTA in the 5'UTR goat MSTN gene has a significant effect on body weight and size (Li et al., 2008) on birth weight, 90-day weight, 300 days age weight and birth body length of Boer goat (Zhang et al., 2012), whereas the indel study of the TTTTA in the 5'UTR MSTN 
gene in Indonesian goats have never been done.

Therefore, the objective of this study was to analyze the genetic diversity of the 5'UTR MSTN gene fragment and associate it with the body weights of Boer, Kacang, and Boerka goats. The results of this study are expected to be used as basic information in the development of goat breeding programs in Indonesia, especially in the Indonesian Goat Research Center, Sungei Putih, Deli Serdang, North Sumatera.

\section{MATERIALS AND METHODS}

\section{Animal and Samples}

This research was carried out in the animal molecular genetics laboratory, Animal Science Faculty, IPB University. One hundred and fortynine blood samples were taken from the Indonesian Goat Research Center, Sungei Putih, Galang, Deli Serdang, North Sumatera. The samples consisted of Boer (30 heads), Kacang (29 heads), and Boerka goats (90 heads). The goats were maintained in one location with the same maintenance management in a cage and given a feeding concentrate and forage feed (Indigofera zoolingeriana, Brachiaria humidicola, Brachiaria ruziziensis, Pennisetum purpureum cv mott). Data were collected during the years of 2016-2018 of body weights at birth (BW), 3 months (M3W), 6 months (M6W), 9 months (M9W), 12 months (M12W), and Average daily body weight gain (ADG) between birth to 12 months of age. Blood samples $3 \mathrm{ml}$ were collected from the jugular vein using a venoject needle and kept in the vacutainer tube containing $\mathrm{K}_{2}$ EDTA anticoagulant, then stored in a refrigerator (temperature $\pm 4^{\circ} \mathrm{C}$ ).

\section{DNA Extraction and 5'UTR MSTN Gene Amplification}

DNA extraction, according to the extraction procedure of Genomic DNA mini kit (Geneaid Biotech Ltd). Amplification using the PCR method with the master cycler gradient machine (ESCO, Singapore). Amplification was performed at a total volume of $25 \mu \mathrm{L}$ consisting of $2.5 \mu \mathrm{L}$ (1.1-15.7 ng) DNA templates, $12.5 \mu \mathrm{L}$ PROMEGA green master mix, $9.4 \mu \mathrm{L}$ nucleasefree water, $0.3 \mu \mathrm{L}(25 \mathrm{pmol})$ forward primer and $0.3 \mu \mathrm{L}(25 \mathrm{pmol})$ reverse primer.

The primer design refers to the National Center for Biotechnology Information (NCBI) with access number EF591039.1. Primer was designed using the Primer 3 program, Multiprimer Analyzer and Primer Stat. The primer design results were a forward primer 5'AAGAGCCAATCACAGATCCC-3' and reverse primer 5'-ACTAGAACAGCAGTCAGCAG-3' with a product length of $635 \mathrm{bp}$. Amplification of MSTN gene DNA through 5 stages. The first stage was the denaturation process at $95^{\circ} \mathrm{C}$ for 5 minutes. The second, third, and fourth stages were cycles repeated 35 times with steps; denaturation at $95^{\circ} \mathrm{C}$ for 10 seconds, annealing at $57^{\circ} \mathrm{C}$ for 20 seconds, and extension at $72^{\circ} \mathrm{C}$ for 30 seconds. The fifth stage ends with elongation primers at $72^{\circ} \mathrm{C}$ for 5 minutes. DNA amplification products were extracted on $1.5 \%$ agarose gel for 35 minutes and photographed using UV Transilluminator. The use of agarose gel according to the procedure of Lee et al. (2012).

\section{DNA Sequencing and PCR-RFLP}

Ninety-five selected samples amplicon with a volume of $22 \mu \mathrm{L}$ for each sample were sequenced by commercial laboratory service at First BASE Laboratories (Malaysia). Direct sequencing using ABI Prism 96-capillary 3730xl DNA analyzer (Applied Biosystems, USA). Indel g.1256-1260 (TTTTA/-) was identified using the PCR-RFLP method on the remaining samples until all (149) samples were identified. PCRRFLP uses the DraI restriction enzyme with a cut site (TTT|AAA). The RFLP was carried out at a total volume of $7.2 \mu \mathrm{L}$ consisting of $5 \mu \mathrm{L}$ of PCR (amplicon) products, $0.9 \mu \mathrm{L}$ nuclease-free water, $0.7 \mu \mathrm{L}$ buffer enzyme, $0.6 \mu \mathrm{L}$ DraI enzyme and incubated at $37^{\circ} \mathrm{C}$ for 12 hours. RFLP products were electrophoresed on $2 \%$ agarose gel for 43 minutes and photographed using UV Transilluminator.

\section{Data Analysis}

Sequencing results were analyzed using the software Finch TV 1.4, Bioedit 7.2, and MEGA 7.0 Tamura et al. (2013). The allele and genotype frequency were calculated with Popgene32, according to Nei and Kumar (2000). HardyWeinberg equilibrium using Popgene 32 with chisquare based on the method of Hartl and Clark (1997). The ANOVA of the 5'UTR MSTN gene was analyzed using SAS 9.4 software (SAS Institute, USA) with a mathematical model of the General Linear Model (GLM) at level probability 0.05 . Further tests were carried out by Least Square Means to find out the significant differences between genotypes. A mathematical model was formulated as follows; $Y_{\mathrm{ijkl}}=\mu+\alpha_{\mathrm{i}}+\beta_{\mathrm{j}}$ 
$+\gamma_{\mathrm{k}}+\mathrm{z}_{\mathrm{l}}+C_{\mathrm{ijklm}}$. Where: $\mu$ is the overall mean for each trait; $\alpha_{i}$ is the effect of $i^{\text {th }}$ genotype, $i$ is $1,2,3$; $\beta_{\mathrm{j}}$ is the effect of $\mathrm{j}^{\text {th }}$ sex, $\mathrm{j}$ is 1,$2 ; \gamma_{\mathrm{k}}$ is the effect of $\mathrm{k}^{\text {th }}$ birth type, $\mathrm{k}$ is $1,2,3 ; \mathrm{z}_{1}$ is the effect of $\mathrm{l}^{\text {th }}$ birth season, 1 is 1,$2 ; \epsilon_{i j k l m}$ is random error.

\section{RESULTS AND DISCUSSIONS}

\section{Polymorphisms in 5'UTR MSTN Gene}

The 5'UTR MSTN gene was successfully amplified using primer at an annealing temperature of $57^{\circ} \mathrm{C}$ for 20 seconds, with a length of PCR product was $635 \mathrm{bp}$ (Figure 1). These results indicate that fragments have excellent specifications and can be further processed through direct sequencing analysis. Visualization of direct sequencing results on finch TV shows that there were three different banding patterns; normal, deletion, and double band until the end of the product sequence (Figure 2). The alignment of sequencing results for the EF591039.1 genebank shows the five base pairs indel (g.1256/TTTTA), but no other SNPs were found (Figure 3). This is in agreement with previous researches which reported the presence of the same indel in eighteen local Chinese goat breeds ( $\mathrm{Li}$ et al., 2008; Zhang et al., 2012), four Iranian goat breeds (Abdolmohammadi et al., 2016) and seven Indian goat breeds (Singh et al., 2014). But, the Indian goats have shown some new SNP besides the TTTTA deletion. Boer and Boerka goats have shown polymorphisms, but monomorphism in Kacang goat (Figure 3). Amplification RFLP product of the 5'UTR MSTN gene (Figure 4) showed three genotypes; AA (635 bp), BB (430 bp, $205 \mathrm{bp})$, and $\mathrm{AB}$ (635 bp, $430 \mathrm{bp}, 205 \mathrm{bp})$.

\section{Genotype and Allele Frequency of 5'UTR MSTN Genes}

PCR-RFLP shows that the 5'UTR MSTN gene in Boer and Boerka goats has three genotypes; AA (deletion), AB (heterozygous), and $\mathrm{BB}$ (normal). But the Kacang goat has only one genotype AA (deletion). The highest AA genotype frequency was in Boerka goats $(0.53)$, the AB genotype was highest in Boer goats $(0.43)$ while the BB genotype had the lowest frequency among the others. Li et al., (2008) and Zhang et al., (2012) reported three genotypes (AA, AB, BB) in local Chinese goats with the frequency of $\mathrm{AA}$ and $\mathrm{AB}$ dominant than BB. Genotype frequencies in seven local Indian goats have only two genotypes (AA, AB) (Singh et al., 2014). One local Iranian goat breed was shown three genotype polymorphisms (AA, AB, BB), but three other breeds have only two genotypes (AA, AB). The results of this study indicate a pattern of genotype frequency in local goats in 4 countries (Indonesia, India, Iran, and China). Chinese local goats have three genotypes, Iranian have 3 and 2 genotypes, local Indian goats have two genotypes, while local Indonesian goats (Kacang) only have one genotype. This is related to the position of the country to the equator. Where the area around the equator is a tropical region bounded by latitude (Reis et al., 2018). Latitude forms 3 main climates (cold zone, temperate climate zone, and hot lowland). In this zone, certain varieties of plants and animals are formed that can adapt to the environment (Asfaw et al., 2019).

This study found two alleles (Table 1) A and $\mathrm{B}$ with the highest frequency in A. A allele in Boer goats was 0.62 and 0.72 in Boerka goats. So, the 5'UTR MSTN gene in Boer and Boerka goats were polymorphic because it had at least two alleles with a relative frequency greater than 0.01 (1\%) (Nei and Kumar, 2000).

\section{Hardy-Weinberg Equilibrium of 5'UTR MSTN Gene in Population}

The enotype balance of 5'UTR MSTN gene in the population was tested by chi-square $\left(\chi^{2}\right)$.

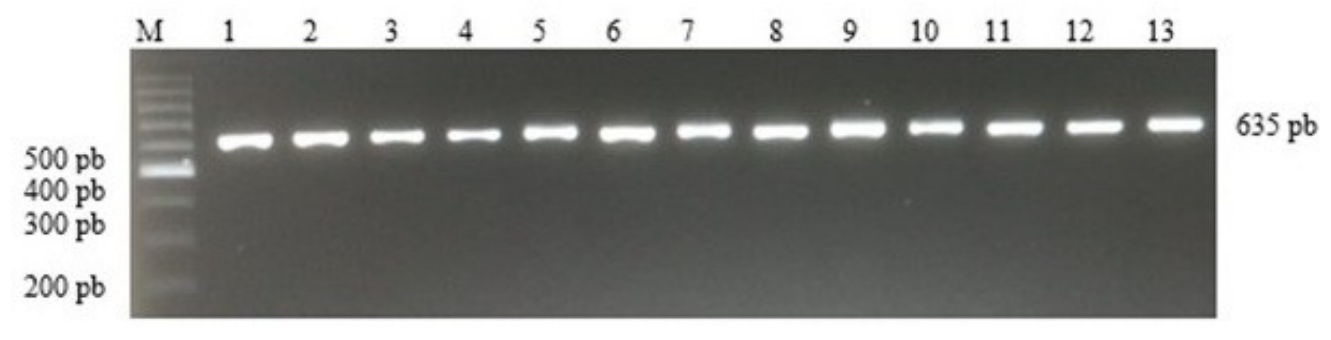

Figure 1. Amplification PCR Product of 5'UTR MSTN Gene Fragment using 1,5\% Agarosa Gel. $\mathrm{M}=$ Marker 100 bp DNA; 1,2,3,.......13 = Sample Code 


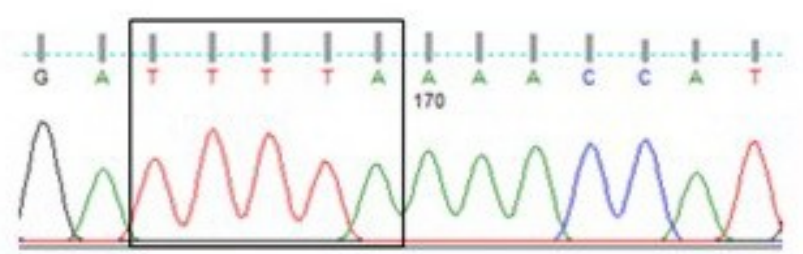

(a) Normal

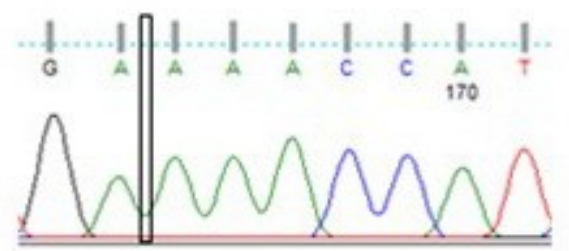

(b) Deletion 5 bp TTTTA

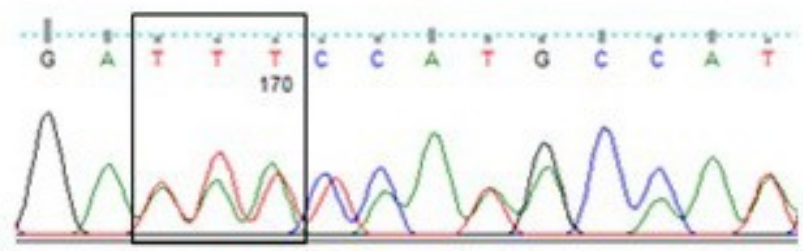

(c) Partial Deletion

Figure 2. Visualization Indel (g.1256/TTTTA) 5'UTR MSTN Gene in Boer, Kacang, and Boerka Goat

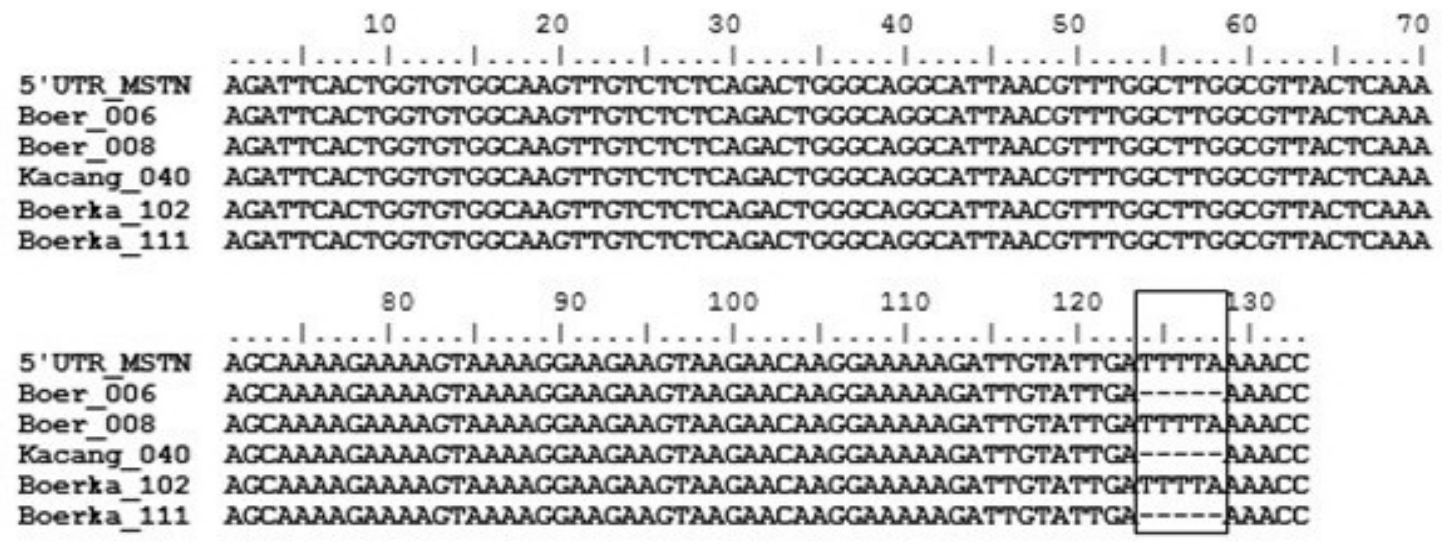

Figure 3. Alignment Partial Sequence 5'UTR MSTN Gene in Boer, Kacang, dan Boerka Goats with GenBank EF591039.1

The $\chi^{2}$ test aims to determine whether the population was still in Hardy-Weinberg Equilibrium (HWE) or not. The population was said to be balanced if the calculated $\chi^{2}$ value was smaller than $\chi^{2}$ tables $(\mathrm{P}<0.05)$ (Allendorf et al., 2013). Boer, Kacang, and Boerka goats were still in HWE (Table 1). The frequency of alleles and genotypes does not change from generation to generation indicates that the population was in balance (Allendorf et al., 2013). HWE only applies to populations that are ideal where there are no disturbances that affect genotype and allele frequencies (Waples and Allendorf, 2015). Therefore the overall principle of HWE makes several assumptions such as; random matting, unlimited population sizes, no mutations, no selection, single population, no migration, nonoverlapping generations, and diploid inheritance (Meirmans, 2018).

Heterozygosity was used to measure the level of genetic diversity in a population-based on allele frequencies. If the objective heterozygosity (Ho) value is greater than the expected heterozygosity $(\mathrm{He})$, the population is diverse (Sharma et al., 2016). Based on Table 1, the five base pairs indel (g.1256/TTTTA) MSTN gene in Boer and Boerka goats has low diversity due to the value of Ho less than He. Ho and He values 


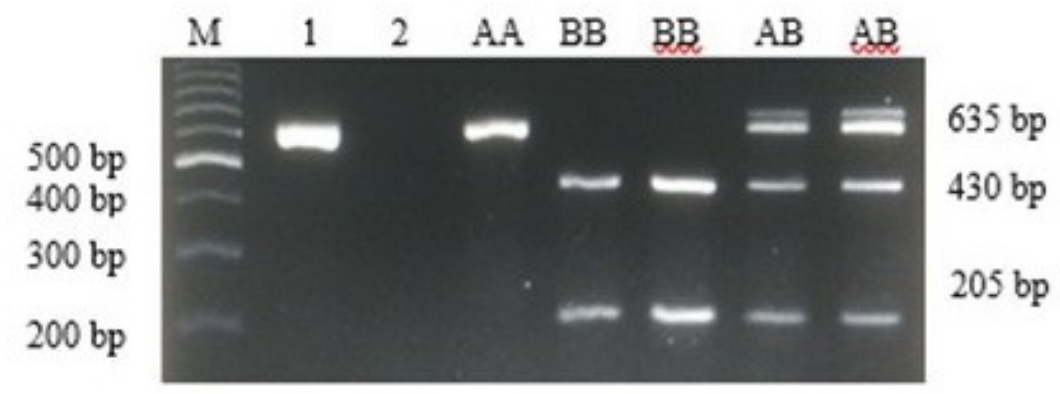

Figure 4. Amplification RFLP product of 5'UTR MSTN gene fragment using 2\% agarosa gel. $\mathrm{M}=$ marker $100 \mathrm{bp}$ DNA, $1=$ DNA template, $2=\operatorname{mix}, \quad \mathrm{AA}=$ deletion, $\mathrm{BB}=$ normal, $\mathrm{AB}=$ heterozygous

Table 1. Result of Statistical Analysis in the Indel 5'UTR MSTN Gene in Boer, Kacang and Boerka Goat

\begin{tabular}{|c|c|c|c|c|c|c|c|c|c|c|}
\hline \multirow{2}{*}{ Marker } & \multirow{2}{*}{$\begin{array}{c}\text { Goat } \\
\text { Population }\end{array}$} & \multirow{2}{*}{ (n) } & \multicolumn{3}{|c|}{ Genotype Frequency } & \multicolumn{2}{|c|}{ Allele Frequency } & \multirow{2}{*}{ Ho } & \multirow{2}{*}{$\mathrm{He}$} & \multirow{2}{*}{$\chi^{2}$} \\
\hline & & & $\mathrm{AA}(\mathrm{n})$ & $\mathrm{AB}(\mathrm{n})$ & $\mathrm{BB}(\mathrm{n})$ & $\mathrm{A}$ & B & & & \\
\hline \multirow{3}{*}{$\begin{array}{l}\text { Indel } \\
\text { g.1256/ } \\
\text { TTTTA }\end{array}$} & $\mathrm{Bc}$ & $(30)$ & $0.40(12)$ & $0.43(13)$ & $0.17(5)$ & 0.62 & 0.38 & 0.43 & 0.47 & $0.30(\mathrm{~ns})$ \\
\hline & Kacang & (29) & $1.00(29)$ & - & - & 1.00 & - & - & - & - \\
\hline & Boerka & $(90)$ & $0.53(48)$ & $0.37(33)$ & $0.10(9)$ & 0.72 & 0.28 & 0.37 & 0.41 & 0.95 (ns) \\
\hline
\end{tabular}

$\mathrm{df}=1 ; \chi^{2}$ table $=3.84 ; \mathrm{ns}=$ non significant

that were not significantly different indicated that there had been selection activities and there was no random matting (Allendorf et al., 2013; Kolenda et al., 2019)

\section{Association of 5'UTR MSTN Gene with Body Weight}

The results of the study (Table 2) five base pairs indel g.1256/TTTTA in the 5'UTR fragment of the MSTN gene were only significant $(\mathrm{P}<0.05)$ to the growth in birth weight of the Boer goat, but not significantly in Boerka goats. However, the indel did not show any significant effect on other parameters such as M3W, M6W, M9W, M12W and ADG, both on Boer and Boerka 04 \pm 0.82 (Zhang et al., 2008), 3.22 \pm 0.13 (Browning et al., 2011) and 3.41 \pm 0.80 (Menezes et al., 2016).

The AA genotype in Boer goat birth weight (BW) was significantly different $(\mathrm{P}<0.05)$ from the $A B$ genotype but not substantially different from the BB genotype. The AA genotype tends to have a higher body weight than the BB genotype in birth weight (BW) and 3 month age weight (M3W). Although it has no real effect, the $\mathrm{AB}$ genotype has a bodyweight that tends to be higher in; 6 months (M6W), 9 months (M9W), 12 months (M12W) of age and daily weight gain (ADG). In this case, the $\mathrm{BB}$ genotype has a bodyweight that is almost the same as the $\mathrm{AB}$ genotype compared to the AA genotype. BB genotype in Boerka goats tends to have the highest body weight in BW, M3W, M9W, M12W, and ADG. Although the three genotypes in Boerka goats did not show statistically significant differences, the highest tendency for body weight was found in $\mathrm{BB}$ and $\mathrm{AA}$ genotypes, compared to $\mathrm{AB}$ genotypes respectively.

Genotype AA was significant $(\mathrm{P}<0.05)$ for the highest birth weight in Boer goat. This shows that 5ÚTR MSTN|DraI can be used to select for birth weight traits in Boer goat in Indonesia. Previous studies found a significant association 
Table 2 Association of Five Base Pairs Indel g.1256/TTTTA with Birth Weight of Boer, Kacang and Boerka Goat

\begin{tabular}{|c|c|c|c|c|c|}
\hline \multirow{2}{*}{$\begin{array}{c}\text { Goat } \\
\text { Population }\end{array}$} & \multirow{2}{*}{ Body Weight } & \multicolumn{3}{|c|}{ Genotype } & \multirow{2}{*}{ Significantly } \\
\hline & & $\mathrm{AA}(\mathrm{n})$ & $\mathrm{AB}(\mathrm{n})$ & $\mathrm{BB}(\mathrm{n})$ & \\
\hline \multirow[t]{6}{*}{ Boer } & BW (kg) & $3.29 \pm 0.19 \mathrm{a}(11)$ & $2.88 \pm 0.48 b(12)$ & $2.96 \pm 0.17 \mathrm{ab}(5)$ & $*$ \\
\hline & M3W (kg) & $10.13 \pm 1.73(11)$ & $9.49 \pm 2.91(11)$ & $9.72 \pm 0.95(5)$ & ns \\
\hline & M6W (kg) & $13.43 \pm 3.82(12)$ & $14.78 \pm 4.59(13)$ & $12.64 \pm 2.54(5)$ & ns \\
\hline & M9W (kg) & $14.84 \pm 3.88(12)$ & $19.05 \pm 5.51(13)$ & $16.52 \pm 5.33(5)$ & ns \\
\hline & M12W (kg) & $18.74 \pm 4.49(12)$ & $24.48 \pm 7.71(13)$ & $20.94 \pm 6.59(5)$ & ns \\
\hline & $\mathrm{ADG}(\mathrm{g} / \mathrm{d})$ & $42.68 \pm 12.24(12)$ & $59.40 \pm 21.33(13)$ & $49.30 \pm 17.92(5)$ & ns \\
\hline \multirow[t]{6}{*}{ Boerka } & BW (kg) & $2.58 \pm 0.50(48)$ & $2.58 \pm 0.44(33)$ & $2.71 \pm 0.65(9)$ & ns \\
\hline & M3W (kg) & $9.70 \pm 3.24(48)$ & $8.61 \pm 2.59(33)$ & $9.72 \pm 3.08(9)$ & ns \\
\hline & M6W (kg) & $13.49 \pm 4.64(48)$ & $11.35 \pm 3.56(33)$ & $12.76 \pm 5.38(9)$ & ns \\
\hline & M9W (kg) & $20.17 \pm 6.59(48)$ & $17.88 \pm 7.29(33)$ & $20.24 \pm 8.61(9)$ & ns \\
\hline & M12W (kg) & $25.48 \pm 7.10(48)$ & $23.33 \pm 8.04(33)$ & $26.76 \pm 9.82(9)$ & ns \\
\hline & $\mathrm{ADG}(\mathrm{g} / \mathrm{d})$ & $62.73 \pm 19.15$ & $56.88 \pm 21.85$ & $65.85 \pm 26.45(9)$ & ns \\
\hline
\end{tabular}

$\mathrm{BW}=$ birth weight; $\mathrm{M} 3 \mathrm{~W}=$ body weight at 3 months age; $\mathrm{M} 6 \mathrm{~W}=$ body weight at 6 months age; $\mathrm{M} 9 \mathrm{~W}=$ body weight at 9 months age; M12W = body weight at 12 months age; $\mathrm{ADG}=$ Average daily body weight gain between birth to 12 months of age; significantly test level (5\%); $\mathrm{n}=$ number of samples; * significant $(\mathrm{P}<0.05) ; \mathrm{ns}=$ non significant

between the indel g.1256/TTTTA markers on the growth traits in several goat breeds in China. Li et al., (2008) report the results of the same study in which the AA genotype significantly affected birth weight up to 3 months of age in eighteen local Chinese goat breeds. The $A B$ genotype in Boer goats was known to have a significant effect $(\mathrm{P}<0.05)$ on birth weight, 90-day weight, and 300day weight (Zhang et al., 2012). However, Bi et al., (2020) reported different results in which the AA genotype in Shaanbei White Cashmere goat had no significant effect on body weight, but had a significant effect $(\mathrm{P}<0.05)$ on body size such as body height and height at the hip cross. All of these studies confirm that the g.1256/TTTTA 5ÚTR MSTN gene indel can be used as a marker gene for the growth traits of goats. But differences in livestock environments between countries have led to variations in genotypic expression that control the nature of the growth.

\section{CONCLUSION}

The five base pairs indel g.1256/TTTTA of 5'UTR MSTN gene fragment was polymorphic in
Boer and Boerka, but monomorphic in Kacang goat. Boer, Kacang, and Boerka goats were still in Hardy-Weinberg equilibrium (HWE). Association of the polymorphism of the MSTN | 5'UTR gene DraI shown a significant difference in birth weight (BW). Genotype AA has only affected the growth of the highest birth weight in Boer goats, but it does not affect the other bodyweight parameters, both in Boer and Boerka goats. Therefore the molecular selection of the MSTN | 5'UTR gene DraI could be used to find the best Boer birth weight with AA genotype, but it is not suitable for Kacang and Boerka goats.

\section{ACKNOWLEDGMENTS}

This research was supported and funded by the Indonesian Agency for Agricultural Research and Development (IAARD) Indonesian Ministerial of Agricultural as a part of the 2019 scholarship package. The author would also like to give thank you to Heads of Indonesian Goat Research Center, Sungei Putih, Galang, Deli Serdang, North Sumatera for providing blood samples of goat and data that were used in this 
study.

\section{REFERENCES}

Abdolmohammadi, A., K. Khani, S. Foroutanifar, A. Zebarjadi, L. Simaei and M. Goli. 2016. Molecular evaluation of the myostatin gene in four Iranian native goat breeds did not demonstrate any association with twining rate. Iran. J. Appl. Anim. Sci. 6(2):375-381.

Aiello, D., K. Patel and E. Lasagna. 2018. The myostatin gene: an overview of mechanisms of action and its relevance to livestock animals. Anim. Genet. 49(6):505-519.

Allendorf, F.W., G. Luikart and S.N. Aitken. 2013. Conservation and the Genetics of Population. Wiley-Blackwell Pub. West Sussex.

Araujo, P.R., Y. Kihoon, K. Daijin, D.S. Andrew, M. Qiao, U. Suresh, C.B. Suzanne and O.F.P. Luiz. 2012. Before it gets started: regulating translation at the 5'UTR. Comp Funct Genom. 2012:1-8.

Arend, K.C., E.M. Lenarcic and N.J. Moorman. 2018. The 5' untranslated region of the major immediate early mRNA is necessary for efficient human Cytomegalovirus replication. J. Virol. 92:e02128-17.

Asfaw, M.D., S.M. Kassa, E.M. Lungu and W. Bewket. 2019. Effects of temperature and rainfall in plant-herbivore interactions at different altitude. Ecol. Modell. 406(5):5059.

Batubara, A. 2017. Myostatin gene expression and ist application on goat breeding programme. Wartazoa 27(2):89-94.

Batubara, A. 2006. Comparison of intestinal worm parasitic infection rates in Costa, Gembrong and Kacang goats. Proceedings. The National Seminar on Animal Husbandry and Veterinary Technology, Puslitbang Peternakan, Bogor, Indonesia. September 56, 2006. P. 555-560.

Batubara, A., F. Mahmilia, I. Inounu, B. Tiesnamurti and H. Hasinah. 2012. Breed of Kacang Goat in Indonesia. IAARD Press. Jakarta.

Bi, Y., B. Feng, Z. Wang, H. Zhu, L. Qu, X. Lan, C. Pan and X. Song. 2020. Myostatin (MSTN) gene indel variation and its associations with body traits in shaanbei white cashmere goat. Animals. 10(1):1-9.

Browning, R.J. and M.L. Leite-Browning. 2011. Birth to weaning kid traits from a complete diallel of boer, kiko, and spanish meat goat breeds semi-intensively managed on humid subtropical pasture. J. Anim. Sci. 89(9):2696-2707.

Chong, Y., G. Liu, X. Jiang, Y. Fu, C. Liu and D. Bo. 2019. Genetic introgression of Boer goat into indigenous goat breeds in the three gorges area of China. Small Rumin. Res. 176(5):1-4.

Doloksaribu, M., S. Elieser, F. Mahmilia and F. Pamungkas. 2005. Kacang goat productivity in caged conditions: birth weight, weaning weight, number of offspring born and preweaning life force. Proceedings. The National Seminar on Animal Husbandry and Veterinary Technology, Puslitbang Peternakan, Bogor, Indonesia, September 12-13, 2005. P. 581-585.

Dominique, J.E. and C. Gérard. 2006. Myostatin regulation of muscle development: Molecular basis, natural mutations, physiopathological aspects. Exp. Cell Res. 312(13):2401-2414.

Elieser, S., S. Sumadi, G.S. Budisatria and S. Subandriyo. 2012. Productivity comparison between Boer and Kacang goat dam. J. Indones. Trop. Anim. Agric. 37(1):15-21.

El Shafey, N., M. Guesnon, F. Simon, E. Deprez, J. Cosette, D. Stockholm, D. Scherman, P. Bigey and A. Kichler. 2016. Inhibition of the myostatin/Smad signaling pathway by short decorin-derived peptides. Exp. Cell Res. 341(2):187-195.

Feng, Y., M. Liu, Z. Wang, X. Zhao, B. Han, Y. Xing, M. Wang and Y. Yang. 2019. A 4-bp deletion in the 5'UTR of TaAFP-B is associated with seed dormancy in common wheat (Triticum aestivum L.). BMC Plant Biol. 19(1):1-10.

García-Muñiz, J.G., R. Ramírez-Valverde, R. Núñez-Domínguez and J.A. HidalgoMoreno. 2019. Dataset on growth curves of Boer goats fitted by ten non-linear functions. Data in Brief. 23(1):1-10.

Ginting, S.P. and F. Mahmilia. 2008. Boerka goat: Meat type goat crossing between Boer and Kacang goat. Wartazoa. 18(3):115-126.

Grisolia, A.B., G.T. D’Angelo, L.R. Porto Neto, F. Siqueira and J.F. Garcia. 2009. Myostatin (GDF8) single nucleotide polymorphisms in Nellore cattle. Genet. Mol. Res. 8(3):822830.

Grochowska, E., B. Borys, D. Lisiak and S. Mroczkowski. 2019. Genotypic and allelic 
effects of the myostatin gene (MSTN) on carcass, meat quality, and biometric traits in Colored Polish Merino sheep. Meat Sci. 151(12):4-17.

Hartl, D.L. and A.G. Clark. 1997. Principle of Population Genetics. Sinaeur Associates. Sunderland.

Hayashi, Y., C. Ogawa, K. Masumoto, F. Katou, S. Mikawa and K. Sato. 2018. Myostatin expression in the adult rat central nervous system. J. Chem. Neuroanat. 94(10):125138.

He, Z., T. Zhang, L. Jiang, M. Zhou, D. Wu, J. Mei and Y. Cheng. 2018. Use of CRISPR/Cas9 technology efficiently targetted goat myostatin through zygotes microinjection resulting in double-muscled phenotype in goats. Biosci. Rep. 38(6):1-25.

Kolenda, M., E. Grochowska, S. Milewski and S. Mroczkowski. 2019. The association between the polymorphism in the myostatin gene and growth traits in Kamieniec and Pomeranian sheep breeds. Small Rumin. Res. 177(6):29-35.

Kvedaras, M., P. Minderis, R. Krusnauskas, A. Lionikas and A. Ratkevicius. 2019. Myostatin dysfunction is associated with lower physical activity and reduced improvements in glucose tolerance in response to caloric restriction in Berlin high mice. Exp. Gerontol. 128(10):1-29.

Lee, P.Y., J. Costumbrado, C.Y. Hsu and Y.H. Kim. 2012. Agarosa gel electrophoresis for the separation of DNA fragments. J. Vis Exp. (62):1-5.

Li, X., Z. Liu, R. Zhou, G. Zheng, Y. Gong and L. Li. 2008. Deletion of TTTTA in 5'UTR of goat MSTN gene and its distribution in different population groups and genetic effect on bodyweight at different ages. Front. Agric. China. 2(1):102-105 .

Liao, L., G. Ning, C. Liu, W. Zhang and M. Bao. 2013. The intron from the 5'UTR of the FBP11 gene in petunia displays promoterand enhancer-like functions. Sci. Hortic. 154(2):96-101.

Manzella, C., M. Singhal, M. Ackerman, W.A. Alrefai, S. Saksena, P.K. Dudeja and R.K. Gill. 2020. Serotonin transporter untranslated regions influence mRNA abundance and protein expression. Gene Reports. 18(10):1-8.

McPherron, A.C. and S.J. Lee. 1997. Double muscling in cattle due to mutations in the myostatin gene. Proceedings. The National Academy of Sciences. Johns Hopkins University School of Medicine, Baltimore, Maryland, United State. Agust 26, 1997. P. 12457-12461.

Meirmans, P.G., 2018. Hardy-weinberg equilibrium. Encycl. Ecol. 3(2):118-126.

Menezes, L.M., W.H. Sousa, E.P. CavalcantiFilho and L.T. Gama. 2016. Genetic parameters for reproduction and growth traits in Boer goats in Brazil. Small Rumin. Res. 136(2):247-256.

Mulyono, R.H., C. Sumantri, R.R. Noor, J. Jakaria and D.A. Astuti. 2018. The prediction of prolificacy using linear body parameters and craniometric analysis in Etawah-grade does. Trop. Anim. Sci. J. 41(2):77-84.

Nei, M. and S. Kumar. 2000. Molecular Evolution and Phylogenetics. Oxford Univ Pr. New York.

Nurgiartiningsih, V.M.A., A. Budiarto, G. Ciptadi, T. Djoharjani, M. Nasich and Subagiyo. 2006. Birth weigh and litter size of crossbred Boer and local Indonesian goat.

Proceedings. The $4^{\text {th }}$ Animal Production and Sustainable Agriculture in the Tropic, Gadjah Mada University, Jogjakarta, Indonesia, November 8-9, 2006. P. 422-425.

Panjono, I.G.S. Budisatria, G. Murdjito, N. Ngadiyono and E. Baliarti. 2012. Reproductive performance of Kacang, Kejobong and Ettawa grade goats does. Proceedings. The $15^{\text {th }}$ AAAP Animal Science Congress, November 26-30, 2012, Thammasat University, Bangkok, Thailand. P. 1274-1277.

Priyanto, D., B. Setiadi, D. Yuliastiani and H. Setiyanto. 2002. The performance of offspring crossing from Kacang goats with Boers and Etawa Peranakans (PE). Proceedings. The National Seminar on Animal Husbandry and Veterinary Technology, Puslitbang Peternakan, Bogor, Indonesia, September 30-Oktober 1, 2002. P. 212-216.

Reis, J., P. Handschumacher, V.S. Palmer and P.S. Spencer. 2018. Climatic Factors Under the Tropics. In Neuroepidemiology in Tropical Health. Academic Press, Elsevier. P. 25-39.

Santoso, Amrozi, B. Purwantara and Herdis. 2016. Sonogram of early pregnancy diagnosis in Kacang goat (Capra hircus). J. Sain Veteriner. 34(2):188-192. 
Septian, A.D., M. Arifin and E. Rianto. 2015. The growth pattern of Kacang goat bucks in Grobogan district. Anim. Agric. J. 4(1):1-6.

Setiadi, B., Subandriyo, M. Martawijaya, K. Diwyanto, I. Sutama, U. Aditia, D. Yuliastini, L. Praharani and D. Priyanto. 2001. Analysis of Genetic Superiority of Crossing Goats. Balai Penelitian Ternak, Puslitbang Peternakan. Bogor.

Singh, S.P., R. Kumar, P. Kumari, S. Kumar and A. Mitra. 2014. Characterization of $5^{\prime}$ upstream region and investigation of TTTTA deletion in 5' UTR of Myostatin (MSTN) gene in Indian goat breeds. Anim. Biotechnol. 25(1):55-68.

Sun, X., L, Li, Z. Liu, D. Zhao, A. Yang, L. Zhou, B. $\mathrm{Wu}$ and J. Tian. 2020. Molecular characterization of the myostatin gene and its regulation on muscle growth in Yesso scallop Patinopecten yessoensis. Aquaculture. 520(1):1-14.

Tamura, K., G. Stecher, Peterson, A. Filipski and S. Kumar. 2013. MEGA6: molecular evolutionary genetics analysis version 6.0 . Mol. Biol. Rep. Evol. 30(10):1-5.

Theil, K., M. Herzog and N. Rajewsky. 2018. Post-transcriptional regulation by $3^{\prime}$ UTRs can be masked by regulatory elements in $5^{\prime}$ UTRs. Cell Rep. 22(2):3217-3226.

Triyantini, R., Sumarlin, H. Setiyanto, B. Setiadi and M. Martawidjaja. 2002. Evaluation of meat quality in various goat races. In Collection of State Budget Research Results for the 2001 fiscal year. Book I Ruminants Cattle. Balai Penelitian Ternak, Puslitbang Peternakan, Bogor. P. 167-180.
Wahyuni, V., L.O. Nafiu and M.A. Pagala. 2016. Phenotype characteristics of qualitative and quantitative Kacang goat in West Muna district. Jitro. 3(1):21-30.

Waples, R.S. and F. Allendorf. 2015. Testing for hardy-weinberg proportions: Have we lost the plot?. J. Hered. 106(1):1-19.

Yue, W., H. Yang, Y. Chen, J. Wang, X. Chen, X. Hou, H. Han and C. Wang. 2020. RNA interference provides insights into the multifunctional profiles of Es-MSTN gene in Eriocheir sinensis. Aquac. Reports. 17(3):18.

Zhang, C., Y. Liu, D. Xu, Q. Wen, X. Li, W. Zhang and L. Yang. 2012. Polymorphisms of myostatin gene (MSTN) in four goat breeds and their effects on Boer goat growth performance. Mol. Biol. Rep. 39(3):30813087.

Zhang, C., L. Yang and Z. Shen. 2008. Variance components and genetic parameters for weight and size at birth in the Boer goat. Livest. Sci. 115(6):73-79.

Zhang, J.L., D. Wang, Y.W. Liang, W.Y. Zhong, Z.H. Ming, D.J. Tang and J.L. Tang. 2018. The gram-negative phytopathogen xanthomonas campestris pv. campestris employs a 5'UTR as a feedback controller to regulate methionine biosynthesis. Microbiol. 164(9):1146-1155.

Zhang, X., F. Wang, Z. Dong, X. Dong, J. Chi, H. Chen, Q. Zhao and K. Li. 2020. A new strain of yellow catfish carrying genome edited myostatin alleles exhibits double muscling phenotype with hyperplasia. Aquaculture. 523(2):1-10. 